\title{
Nitrogen loss by volatilization of nitrogen fertilizers applied to coffee orchard
}

\author{
Perdas de nitrogênio por volatilização de fertilizantes \\ nitrogenados em cultivo de café
}

\author{
Anderson William Dominghetti ${ }^{1}$, Douglas Ramos Guelfi ${ }^{2}$, Rubens José Guimarães ${ }^{1}$, \\ André Luiz Carvalho Caputo ${ }^{2}$, Carlos Roberto Spehar ${ }^{3}$, Valdemar Faquin ${ }^{2}$
}

\author{
${ }^{1}$ Universidade Federal Lavras/UFLA, Departamento de Agricultura/DAG, Lavras, MG, Brasil \\ 2Universidade Federal Lavras/UFLA, Departamento de Ciência do Solo/DCS, Lavras, MG, Brasil \\ ${ }^{3}$ Universidade de Brasília/UnB, Faculdade de Agronomia e Medicina Veterinária/FAV, Brasília, DF, Brasi \\ *Corresponding author: douglasguelfi@dcs.ufla.br \\ Received in august 18, 2015 and approved in october 5, 2015
}

\begin{abstract}
Ammonia volatilization $\left(\mathrm{N}-\mathrm{NH}_{3}\right)$ is one of the main pathways of Nitrogen loss reducing nitrogen use efficiency in coffee orchard. This work aimed at quantifying ammonia volatilization $\left(\mathrm{N}_{-} \mathrm{NH}_{3}\right)$ losses from $\mathrm{N}$-sources to be used in coffee plantations fertilization in Brazil. The experiment was conducted in the field on a dystrophic red latosol (Ferralsol in FAO's classification) at the Coffee Research Sector, University of Lavras, MG, Brazil. The experimental design was of complete randomized blocks with three repetitions of the following treatments: conventional urea, ammonium nitrate and urea $+0.15 \% \mathrm{Cu}$ and $0.4 \% \mathrm{~B}$, urea + anionic polymers, urea + elementary sulfur $\left(\mathrm{S}^{\circ}\right)+$ polymers, and urea + plastic resin. These $\mathrm{N}$ sources were split into three doses of $150 \mathrm{~kg} \mathrm{ha}^{-1}$ and band applied. The $\mathrm{N}-\mathrm{NH}_{3}$ losses by volatilization and variations of $\mathrm{pH}$ $\left(\mathrm{H}_{2} \mathrm{O}\right)$ were measured, before and after $\mathrm{N}$ application. The $\mathrm{N}$-sources contributed to reduce the soil $\mathrm{pH}$, measured after the third nitrogen fertilization. The $\mathrm{N}-\mathrm{NH}_{3}$ losses by volatilization (average from three applications) was as follows: urea + anionic polymers $(35.8 \%)>$ conventional urea $(31.2 \%)=$ urea $+\mathrm{S}^{0}+$ polymers $(31.0 \%)>$ urea $+0.15 \% \mathrm{Cu}+0.4 \% \mathrm{~B}(25.6 \%)>$ urea + plastic resin $(8.6 \%)=$ ammonium nitrate $(1.0 \%)$.
\end{abstract}

Index terms: Coffee arabica; slow and controlled release and stabilized fertilizers; ammonium nitrate; urea.

\section{RESUMO}

A volatilização de amônia é uma das principais causas da redução da eficiência no uso de fertilizantes nitrogenados em lavouras cafeeiras. Neste trabalho, objetivou-se quantificar as perdas de nitrogênio por volatilização de fertilizantes nitrogenados aplicados em lavoura cafeeira. O experimento foi realizado em condições de campo, em um Latossolo Vermelho distrófico, cultivado com café, localizado no Setor de Cafeicultura/Departamento de Agricultura/UFLA, Lavras - MG. O delineamento experimental foi em blocos casualizados e os tratamentos foram: ureia; nitrato de amônio; ureia + 0,15\% de Cu + 0,4\% de B; ureia + polímeros; ureia + enxofre elementar $\left(\mathrm{S}^{\circ}\right)+$ polímeros e; ureia + resina plástica; distribuídos em três parcelamentos com doses iguais de $150 \mathrm{~kg} \mathrm{ha}^{-1}$. Foram quantificadas as perdas de nitrogênio por volatilização $\left(\mathrm{N}-\mathrm{NH}_{3}\right)$ e as variações no $\mathrm{pH}$ em água, da camada de 0-5 cm de solo, antes e depois dos parcelamentos das adubações nitrogenadas. Os fertilizantes nitrogenados reduziram os valores do pH do solo após as três adubações de manutenção. A perda de nitrogênio por volatilização dos fertilizantes nitrogenados (média das três adubações) foi: ureia + polímeros ( $35,8 \%$ do total do $\mathrm{N}$ aplicado) $>$ ureia $(31,2 \%)=$ ureia $+\mathrm{S}^{0}+$ polímeros $(31,0 \%)>$ ureia $+\mathrm{Cu}+\mathrm{B}(25,6 \%)>$ ureia + resina plástica $(8,6 \%)=$ nitrato de amônio $(1,0 \%)$.

Termos para indexação: Coffee arabica; fertilizantes estabilizados e de liberação controlada; nitrato de amônio; ureia.

\section{INTRODUCTION}

The agronomic efficiency of conventional fertilizers and the reduction of nitrogen $(\mathrm{N})$ loss are the main objectives in fertility management because these practices reduce the production costs and negative environmental impacts (Trenkel, 2010; Fan et al., 2010). The increase in the efficiency of $\mathrm{N}$ fertilization of field crops has been a major concern for decades (Chien; Prochnow; Cantarella, 2009). Intensive research aims at solving the threat of $\mathrm{N}$ loss in the form of ammonia.
Technologies directly related to FAE include key soil and crop components such as improving the soil profile to create appropriate conditions for the development of the root system; fertility monitoring and nutrition based on soil and plant analysis; and soil acidity amendment. In this context, a slow and controlled release of stabilized $\mathrm{N}$ sources has been a goal to increase the fertilization efficiency and reduce the adverse environmental effects. Indeed, the objectives of any type of $\mathrm{N}$ fertilization are to avoid losses due to volatilization, leaching and denitrification (Chien; Prochnow; Cantarella, 2009; Trenkel, 2010). 
Volatilization has been the main cause of $\mathrm{N}$ loss in Brazilian agriculture, and it is caused by a chemical reaction that converts ammonium ions $\left(\mathrm{NH}_{4}^{+}\right)$into ammonia $\left(\mathrm{NH}_{3} \uparrow\right)$, which is influenced by edaphic and climatic conditions (Sanz-Cobena et al., 2008). The N volatilization reaction occurs when NBPT that has been added to urea granules acts as a urease activity inhibitor in the soil. Several compounds have been found to reduce the conversion of urea $\left[\left(\mathrm{NH}_{2}\right)_{2} \mathrm{CO}\right]$ into ammonium and, ultimately, ammonia in soil (Roberts, 2014). The main substances and elements that have been used for this purpose are NBPT (Watson et al., 2008; Cantarella et al., 2008; Menendez et al., 2009; Pereira et al., 2009; Trenkel, 2010; Silva et al., 2011), copper (Cu) and boron (B) (Krajewska; Zaborska; Chudy, 2004; Heringer, 2008; Gabrovska; Godjevargova, 2009; Faria et al., 2013; Nascimento et al., 2013; Stafanato et al., 2013).

Several inhibitors have been identified in those three groups of compounds, including those that are utilized most frequently in major cropping areas of the world: a) NBPT, Cu and B; b) sulfhydryl; c) urea analogs; and d) molecules that react with nickel (Krajewska; Zaborska; Chudy, 2004).

In addition to stabilized urea, there is another group that belongs to the coated or encapsulated fertilizers. These fertilizers are produced via the addition of compounds that cover the urea granules, reduce their exposure to water and air, and block volatilization. Various products have been developed to suit ammonia volatilization and enhance urea efficiency, thus creating ample innovation possibilities; the products include sulfur, polymers, polystyrene, polyesters, polyurethane, fatty acids, latex, petroleum by-products, magnesium and calcium phosphate, gypsum, Azadhiractha (Neem tree) extract and wax (Trenkel, 2010; Chien; Prochnow; Cantarella, 2009).

These coating substances act as granule sealants, control the dissolution rate and the time required to release the nutrient and allow the synchrony between availability and demand by crops. These fertilizers are divided into three main groups, according to the covering agent: 1) sulfur; 2) sulfur added to polymers; and 3) polymeric and polyolefin matrices (Trenkel, 2010). The controlled release of nutrients from $\mathrm{N}$ fertilizers by these coating agents is considered a promising technology for improving the efficiency of $\mathrm{N}$ fertilization (Yang, 2012).

The use of these innovative $\mathrm{N}$ sources has been restricted to certain crops, especially in developing countries, because efforts were devoted to mastering the technology (Shoji, 2005; Du; Zhouw; Shaviv, 2006;
Du et al., 2008; Yang, 2012). However, with a Chinese contribution and the installation of fertilizer plants in various countries, the slow-release nutrient sources have become available for the agricultural production, especially those coated with sulfur, sulfur and polymers or polymers alone (Sanders; Mazo; Mazo, 2008; Lupwayi et al., 2010; Ogle; Sims, 2012).

Certain N sources have been developed with the use of value-added compounds, which restrict their application to nurseries, horticulture, orchids, golf pitch and lawns. The high cost of coating the granules has been the limiting factor in extending their use to large-scale agriculture (Trenkel, 2010; Yang, 2012).

Considering the value of these innovative fertilizer sources, the aim of this work was to evaluate the $\mathrm{N}^{-\mathrm{NH}_{3}}$ loss through the volatilization of the conventional sources of urea and urea coated with $0.15 \% \mathrm{Cu}$ and $0.4 \% \mathrm{~B}$, plastic resins and with polymers and elementary sulfur added as polymers.

\section{MATERIAL AND METHODS}

The experiment was conducted between August 2013 and August 2014 on a dystrophic red latosol (Ferralsol in the FAO's classification) at the Coffee Research Sector of the University of Lavras, Minas Gerais state, Brazil. The climate, according to Köppen, is classified as Cwa. The average annual temperature recorded between 1961 and 1994 was $19.4^{\circ} \mathrm{C}$, and the average rainfall during the same period was $1,530 \mathrm{~mm}$. The rainfall was concentrated between October and March and was followed by a long dry period in the remaining six months. Before setting the experiment, soil samples were collected at $0-20 \mathrm{~cm}$ depth. To prepare for the analysis, sods were broken into fine particles; the soil was sieved using $4 \mathrm{~mm}$ mesh and allowed to air dry. Subsequently, the soil was further sieved with $2 \mathrm{~mm}$ mesh, and sub-samples were taken for chemical and physical analyses (Table 1).

The following chemical determinations were made: $\mathrm{pH}, 1: 2.5$ soil and water; $(\mathrm{H}+\mathrm{Al}), 0.5 \mathrm{~mol} \mathrm{~L}^{-1} \mathrm{Ca}(\mathrm{OAc})_{2}$ at $\mathrm{pH}$ 7.0; exchangeable $\mathrm{Ca}^{2+}, \mathrm{Mg}^{2+}$ and $\mathrm{Al}^{3+}$ using $1.0 \mathrm{~mol}$ $\mathrm{L}^{-1} \mathrm{KCl}$ extractant and titrimetry; $\mathrm{P}$ and $\mathrm{K}$ using Mehlich-1 extractant and colorimetry $(\mathrm{P})$; flame photometry $(\mathrm{K})$; carbon oxidation with potassium dichromate; $\mathrm{Zn}, \mathrm{Mn}$ and $\mathrm{Cu}$ using Mehlich-1 extractant; and atomic absorption spectrophotometry. The values for an effective CEC ( $t$ ), $\mathrm{CEC}$ at $\mathrm{pH} 7.0(\mathrm{~T})$ and the rates of base saturation (BS \%) and aluminum $(\mathrm{m})$ were indirectly obtained using potential acidity values, exchangeable bases and exchangeable aluminum. 
Table 1: Soil chemical analysis(1) and texture(2) of coffee orchard area.

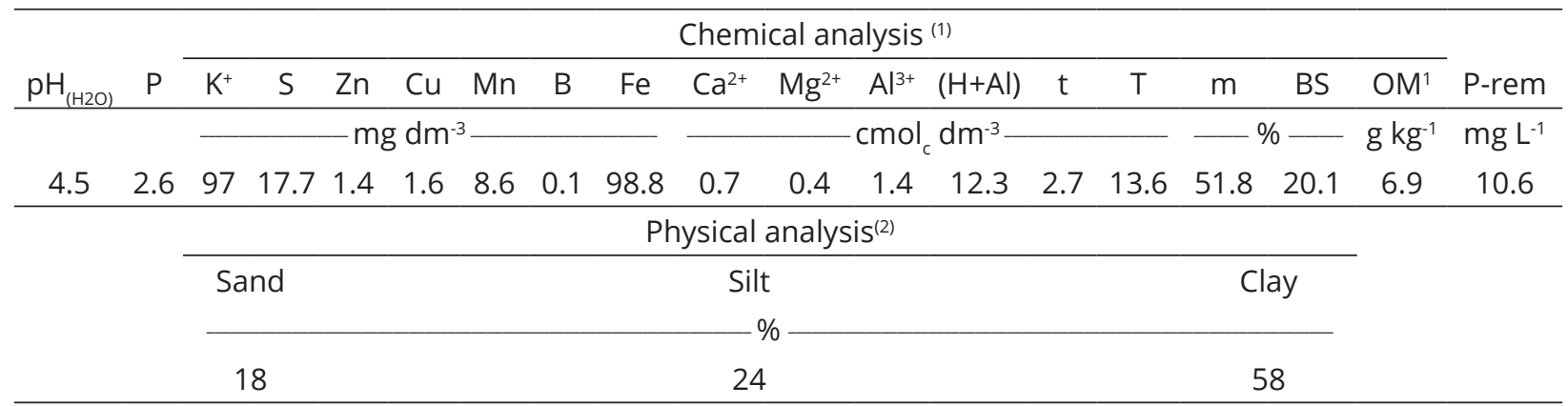

${ }^{1}$ Organic Matter.

The experiment had a complete randomized block design with three replications, and it included the following treatments: urea, ammonium nitrate, urea $+\mathrm{Cu}+\mathrm{B}$, anionic polymer-coated urea, sulfur 7.9\% (elementary sulfur $\left.=\mathrm{S}^{0}\right)$ coated urea + polymers and plastic resin-coated urea. All of the nitrogen fertilizers were applied manually in three nitrogen fertilization times: November/ $1{ }^{\text {st }}$ fertilization, January $/ 2^{\text {nd }}$, and March $/ 3^{\text {rd }}$. The fertilizations occurred at equal rates of $150 \mathrm{~kg} \mathrm{ha}^{-1}$, i.e., a total of $450 \mathrm{~kg} \mathrm{ha}^{-1}$ of $\mathrm{N}$ was used in a single coffee season.

The fertilizer characteristics are as follows: a) Urea - granular urea with $45 \% \mathrm{~N}$; b) Urea $+0.15 \% \mathrm{Cu}$ + B: Urea fertilizer prilled with $44.6 \% \mathrm{~N}$ and with 1.5 $\mathrm{g} \mathrm{kg}^{-1}$ of $\mathrm{Cu}$ in the form of copper sulfate and $4 \mathrm{~g} \mathrm{~kg}^{-1}$ of $\mathrm{B}$ in the form of boric acid. Both copper sulfate and boric acid had particle sizes less than $0.015 \mathrm{~mm}$ and were evenly spread over the granules in the rotating drum (Heringer, 2008); c) Anionic polymer-coated granular urea: anionic polymer-coated urea with $41 \%$ of N. Polymers had negative charges to retain ammonium $\left(\mathrm{NH}_{4}^{+}\right.$; positive charge) that was dissolved in the soil solution near the urea granules. d) Sulfur-coated urea + polymers (Blend): Urea coated with an elemental sulfur layer and an organic polymer that acted as a sealing wax for the sulfur layer. The proportion of polymer coated sulfur urea represented $30 \%$, and the remaining $70 \%$ was composed of the total $\mathrm{N}$ in the form of conventional granular urea (with no coating) for an immediate $\mathrm{N}$ release. This blend of coated urea allowed a controlled nitrogen release due to the presence of a physical barrier, which prevented its dissolution in water. The total nitrogen content was $40 \%$, with $7.9 \%$ elemental sulfur $\left(\mathrm{S}^{0}\right)$. According to the supplier, the nitrogen is released for up to three months; e) Urea coated with a copolymer of ethylene acrylic. This formula of coated urea consisted of a primary controlled release polymer- coated technology. The polymer was springy and controlled the nutrient release by diffusion according to the temperature and humidity. All of the mentioned fertilizers are commercial products.

The experimental plots had 12 equally spaced plants $(3.7 \mathrm{~m}$ between rows and 0.7 between plants). The harvest area had 10 plants because we excluded the borders.

The experimental area was amended with $1.74 \mathrm{tha}^{-1}$ lime, equivalent to $100 \%$ calcium carbonate, as indicated by the soil analysis 60 days before the maintenance fertilization. The rate of nitrogen was $450 \mathrm{~kg} \mathrm{ha}^{-1}$ and potassium maintenance equal $300 \mathrm{~kg} \mathrm{ha}^{-1} \mathrm{~K}_{2} \mathrm{O}$ split into three doses applied every 60 days from 19/11/2013. The phosphate fertilizer source was applied in a single dose. The respective sources were potassium chloride $(60 \%$ $\left.\mathrm{K}_{2} \mathrm{O}\right)$ and super phosphate $\left(20 \% \mathrm{P}_{2} \mathrm{O}_{5}\right)$. Micronutrients such as boron, zinc and copper were applied on the leaves.

During the experiment, soil samples were collected at a depth of $0-5 \mathrm{~cm}$ to assess the $\mathrm{pH}$ variations in the layer where the $\mathrm{N}$ fertilizers were applied.

The rate of ammonia volatilization was determined by a semi-open static collector adapted from the methods described by Lara-Cabezas (1999). Polyvinyl chloride tubes $(20 \mathrm{~cm}$ in diameter and $50 \mathrm{~cm}$ long) were inserted in the soil at a depth of $5 \mathrm{~cm}$ under the tree canopy $(0.35$ $\mathrm{m}$ from plagiotropic branches). Two rubber foam discs $\left(0.02 \mathrm{~g} \mathrm{~cm}^{-3}\right.$ density and $2.5 \mathrm{~cm}$ thick) of same diameter as the tubes were imbibed in phosphoric acid $\left(\mathrm{H}_{3} \mathrm{PO}_{4}\right)$ and glycerin and placed inside tubes at 25 and $45 \mathrm{~cm}$ from the soil surface. The upper foam had the function of avoiding contamination from the lower foam. Evaluations on the volatilized ammonia were made at one, two, three, four, five, seven, nine, twelve, fifteen, nineteen, twenty-three and thirty days after the $\mathrm{N}$ fertilizers' application. On the third $\mathrm{N}$ application, the evaluations were extended 
to sixty-six days after the fertilization or until the fluxes of ammonia were still detected.

The determination of the $\mathrm{N}$ that was captured from volatilization was made as follows: the foams were washed with distilled water over a porous tile Buchner funnel and with the help of a vacuum pump. The extracted volume from the foams was measured, and aliquots were transferred to test tubes and distilled in semi-micro Kjeldahl.

The data for every treatment were subjected to an analysis of variance using the SISVAR $4.3^{\circledR}$ statistical program (Ferreira, 2011). Linear, quadratic, logarithmic and exponential models were tested, and we chose the one that had the highest regression coefficient; the significance level was set at $\mathrm{p} \leq 0.05$ for the $\mathrm{F}$ test.

\section{RESULTS AND DISCUSSION}

There was a significant influence of the nitrogen fertilizer sources in the in the daily and accumulated $\mathrm{N}$ loss for the three $\mathrm{N}$ fertilizations of the coffee orchard $(\mathrm{p} \leq 0.05)$. The variations in accumulated (Figure 1a) and daily volatilization (Figure $1 \mathrm{~b}$ ) were associated with rainfall, temperature and relative air moisture (Figure 1c) during the 27 days after the first fertilization (Figure 1).

The accumulated and daily ammonia loss of the first fertilization varied significantly with the time of application and the $\mathrm{N}$ fertilizer sources $(\mathrm{p} \leq 0.05$; Figure $1 \mathrm{a}, 1 \mathrm{~b}$ ). The urea, urea + anionic polymers and Urea $+\mathrm{S}^{0}$ + polymers had the highest volatilization peaks of $5 \%$, $5.7 \%$, and $6.1 \%$, respectively, at the $2^{\text {nd }}$ day after the band application of $\mathrm{N}$. The coated urea with $0.15 \% \mathrm{Cu}$ and $0.4 \%$ $\mathrm{B}$ had the maximum volatilization in the $3^{\text {rd }}$ day $(6.2 \%$; Figure 1b).

The accumulated rainfall after the first application was $333.4 \mathrm{~mm}$, with $0.6,0.8,1.2,12.6,33,30$, and $0.4 \mathrm{~mm}$ of precipitation between the $1^{\text {st }}$ and $8^{\text {th }}$ days. In the same period, the mean air temperature was $22.2^{\circ} \mathrm{C}$ (Figure 1c).

The urea + plastic resin did not show a high loss of $\mathrm{N}-\mathrm{NH}_{3}$, and the maximum daily volatilization between the $5^{\text {th }}$ and $14^{\text {th }}$ days for this $\mathrm{N}$ source was $0.26 \%$ and $0.33 \%$ of the total $\mathrm{N}$ applied, respectively. The exception of urea + plastic resin in relation to the others nitrogen fertilizers was the high rates of $\mathrm{N}^{-\mathrm{NH}_{3}}$ loss that occurred during the first seven days after the first application. The sequence of accumulated $\mathrm{N}-\mathrm{NH}_{3}$ loss was, in decreasing order, urea + anionic polymers $(32.6 \%)=$ urea $+\mathrm{S}^{0}+$ polymers $(29.6 \%)$ $=$ conventional urea $(28.3 \%)>$ urea $+0.15 \% \mathrm{Cu}+0.4 \% \mathrm{~B}$ $(25.4 \%)>$ urea + plastic resin $(1.4 \%)=$ ammonium nitrate
$(0.7 \%)$. It became evident that the urea + plastic resin and the ammonium nitrate are similar with regards to the reduced $\mathrm{N}$ loss by volatilization. Currently, the ammonium nitrate has a lower price in the Brazilian fertilizer market compared with the urea + plastic resin (Figure 1a).

The copper and boron, among several substances, compounds and chemical elements, are the ones that most inhibited the urease activity in the soil. There are three mechanisms involved in the inhibition of urease. The first is based on a reaction of the inhibiting substances with sulfhydryl, which blocks the active site of the enzyme. Ions such as $\mathrm{Ag}^{+}, \mathrm{Hg}^{+}$and $\mathrm{Cu}^{2+}$ cause an inhibition that is proportional to the solubility of the metal-sulfite product. In the second mechanism, compounds similar to urea, such as thio-urea, methyl-urea, and replaced urea, compete to inhibit the urease activity, which render them inefficient when high $\mathrm{N}$ doses are applied in the form of urea. The third mechanism to inhibit the urease activity is based on the addition of molecules that react with the Ni present in the enzyme (Krajewska; Zaborska; Chudy, 2004).

Another chemical element that inhibits the urease enzyme is boron, which is routinely added in the form of boric acid $\left(\mathrm{H}_{3} \mathrm{BO}_{3}\right)$ to fertilizers for two purposes: supply the boron element as a nutrient and diminish the $\mathrm{N}$ loss by volatilization. The maximum urease inhibition in the region of urea solubility occur in $\mathrm{pH}$ values from 6.2 to 9.3 , which indicates that only the neutral trigon anion $\mathrm{H}_{3} \mathrm{BO}_{3}{ }^{0}$ can inhibit the urease, instead of the $\mathrm{H}_{4} \mathrm{BO}_{4}$. Due to its structural similarity to urea, the boric acid molecule is also considered an analog substrate. Boric acid almost exactly replaces the water molecules bonded to $\mathrm{Ni}$ in the center of reaction (Benini et al., 2004).

The effect of adding $\mathrm{Cu}, \mathrm{B}$ and $\mathrm{S}$ to the urea reduces the $\mathrm{N}$ loss compared with that observed by adding urea alone in maize and sugar cane (Faria et al. 2013; Nascimento et al. 2013).

When the second application of $\mathrm{N}$ is considered, the order of $\mathrm{N}$ loss was as follows: urea + anionic polymers $(30.1 \%)=$ urea $+\mathrm{S}^{0}+$ polymers $(23.6 \%)=\operatorname{urea}(22.1 \%)>$ urea $+0.15 \% \mathrm{Cu}+0.4 \% \mathrm{~B}(17.1 \%)>$ urea + plastic resin $(3.7 \%)>$ ammonium nitrate $(0.1 \%)$; (Figure $2 \mathrm{a})$.

The rainfall after the second $\mathrm{N}$ fertilization was $16.2 \mathrm{~mm}$ at day one and 82, 1.2, 7, 67.4, 5.6, 0.6 and 0.4 $\mathrm{mm}$ in the period between the $2^{\text {nd }}$ and $8^{\text {th }}$ days (Figure $2 \mathrm{c}$ ), with a reduced $\mathrm{N}$ loss in the form of ammonia.

The maximum daily $\mathrm{N}$ volatilization from the urea + polymers $(9.8 \%)$, urea $(8.4 \%)$ and urea $+\mathrm{S}^{0}+$ polymers $(7.3 \%)$ occurred on the $2^{\text {nd }}$ day. The copper and boron-coated urea delayed the volatilization peak $(6.1 \%)$ in the $2^{\text {nd }} \mathrm{N}$ application (Figure $2 \mathrm{~b}$ ). 


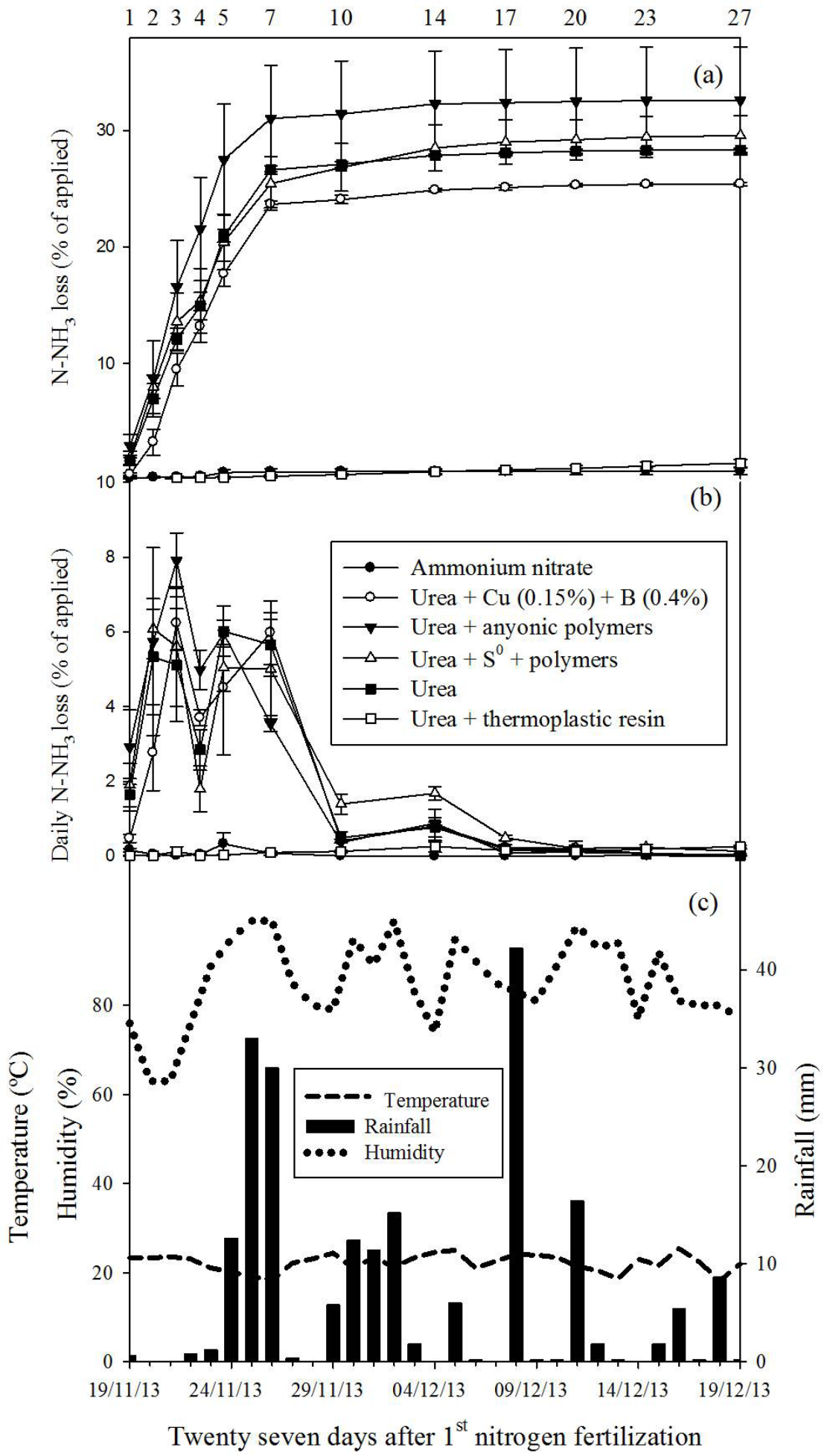

Figure 1: Accumulated (a) and daily (b) $\mathrm{N}-\mathrm{NH}_{3}$ loss, volatilized from fertilizers (conventional urea, ammonium nitrate, urea $+0.15 \% \mathrm{Cu}+0.4 \% \mathrm{~B}$, urea + anionic polymers, urea $+\mathrm{S}^{0}+$ polymers and urea + plastic resin), $1^{\text {st }}$ application $\left(150 \mathrm{~kg} \mathrm{ha}^{-1}\right) \mathrm{N}$, in coffee orchard, relating to climate data (c). 


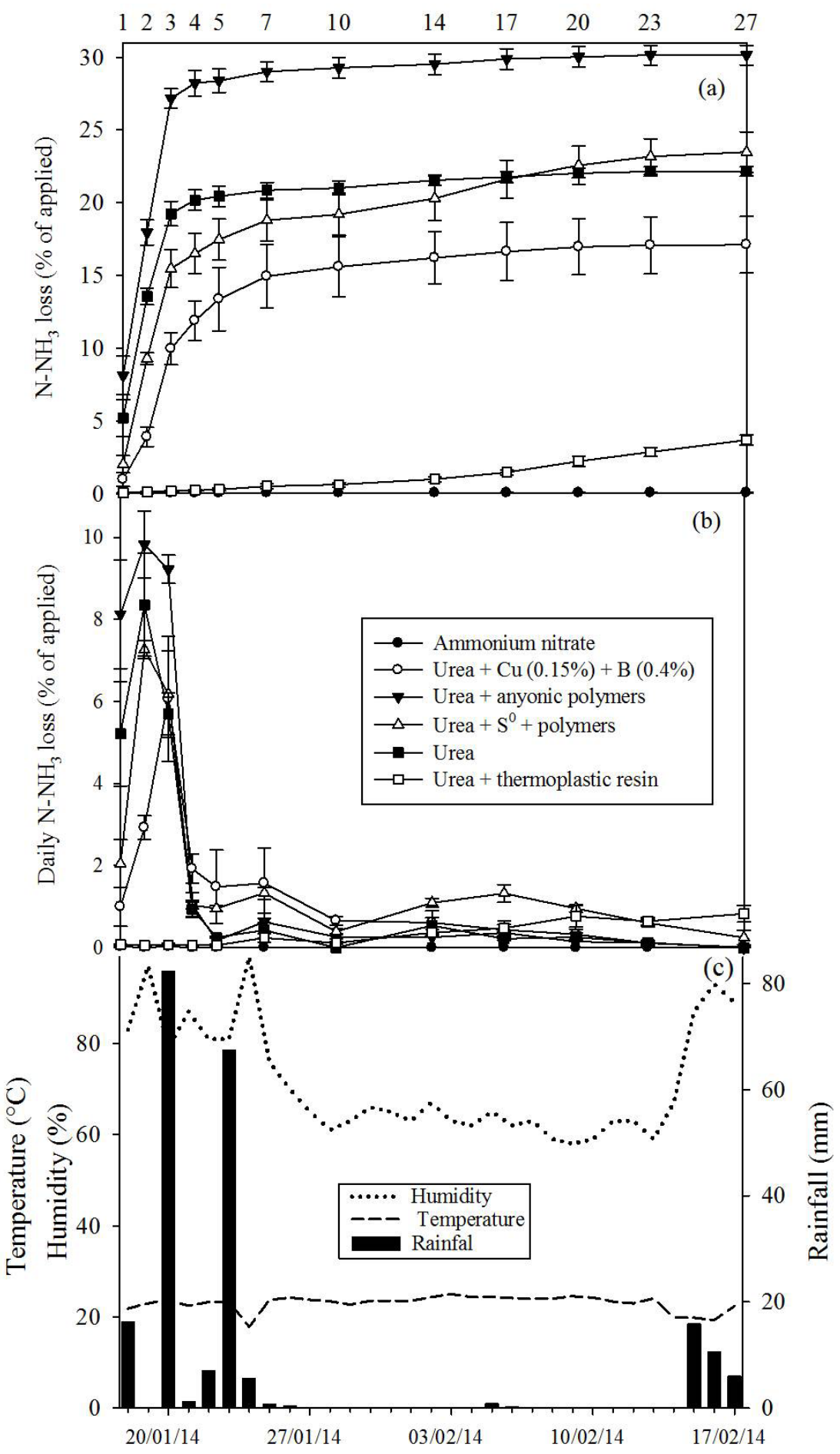

Twenty seven days after $2^{\text {nd }}$ nitrogen fertilization

Figure 2: Accumulated (a) and daily (b) $\mathrm{N}-\mathrm{NH}_{3}$ loss, volatilized from fertilizers (conventional urea, ammonium nitrate, urea $+0.15 \% \mathrm{Cu}+0.4 \% \mathrm{~B}$, urea + anionic polymers, urea $+\mathrm{S}^{0}+$ polymers and urea + plastic resin), $2^{\text {nd }}$ application $\left(150 \mathrm{~kg} \mathrm{ha}^{-1}\right) \mathrm{N}$, in coffee orchard, relating to climate data (c). 
As observed in the first application of $\mathrm{N}$ sources, the ammonium nitrate and urea + plastic resin showed no peaks of daily volatilization of $\mathrm{N}-\mathrm{NH}_{3}$. The addition of plastic resin was, therefore, effective for the gradual release of $\mathrm{N}$ from the granules to the soil solution. Coating the urea granule with resin causes a reduction in the dissolution rate. In the presence of water, the resin membrane becomes permeable by diffusion, and the $\mathrm{N}$ release begins inside the granule. The solution formed at the beginning of the dissolution permeates gradually through the coat, contrary to the water flow, and releases $\mathrm{N}$ to the soil by diffusion $(\mathrm{Du}$ et al., 2006; Du et al., 2008; Trenkel, 2010; Ogle; Sims, 2012; Yang, 2012).

The nitrogen fertilizer with a controlled release such as the urea + resin used in this study possess advantageous attributes such as a reduction in the number of applications, $\mathrm{N}_{-} \mathrm{NH}_{3}$ loss by volatilization, leaching and denitrification, as well as labor requirements and application costs (Ogle; Sims, 2012; Wilson; Rosen; Moncrief, 2010; Wang; Cui; Zhou, 2011). Therefore, the urea + resin is more advantageous when it is applied in one dose at the beginning of the coffee season than when it used in the three split applications that are usually applied in Brazil. Moreover, these sources contribute to the synchrony between the release and absorption curve (Yang, 2012). However, one limitation is the high cost of their production due to the type of materials that are required to coat the granules. The use of these sources has been restricted to value crops (Trenkel, 2010; Yang, 2012) and, eventually, to field crops when their market price is high.

The urea with controlled release promoted a high efficiency compared with the regular urea in the rice cultivation by increasing the $\mathrm{N}$ availability near the root system and the absorption by plants. Similarly, it promotes an enzymatic activity related to the $\mathrm{N}$ metabolism. This relative efficiency allowed a reduction in the $\mathrm{N}$ dose and positively impacted the production costs and the effects on the environment (Wang, 2011).

There was significant difference in the ammonia loss among nitrogen fertilizer during the $3^{\text {rd }}$ nitrogen fertilization $(\mathrm{p} \leq 0.05)$. The accumulated $\mathrm{N}-\mathrm{NH}_{3}$ loss by volatilization from fertilizer sources 66 days after the $3^{\text {rd }}$ application on coffee plants was the following: urea + polymers $(44.7 \%)=$ urea $(43.2 \%)=$ urea $+\mathrm{S}^{0}+$ polymers $(39.8 \%)>$ urea $+0.15 \% \mathrm{Cu}+0.4 \% \mathrm{~B}(34.3 \%)>$ urea + plastic resin $(20.5 \%)>$ ammonium nitrate $(0.2 \%$; Figure $3 \mathrm{a})$. The urea + plastic resin and the ammonium nitrate reduced the accumulated $\mathrm{N}-\mathrm{NH}_{3}$ loss.
The rainfall after the $3^{\text {rd }}$ application of $\mathrm{N}$ fertilizers was $159.6 \mathrm{~mm}$, and it was the least of these three periods, with $4.8,0.4$, and $12.4 \mathrm{~mm}$ on the $2^{\text {nd }}, 3^{\text {rd }}$, and $4^{\text {th }}$ days, respectively. The mean temperature was $21.7^{\circ} \mathrm{C}$. The low rainfall contributed to an increase in the accumulated ammonia loss. The relative air moisture was $>75 \%$ on 16 of the 30 days after the $\mathrm{N}$ application (Figure 3c), which contributed to a rapid urea dissolution in the soil. In addition, the low rainfall kept the dissolved urea near the soil surface and exposed it to volatilization.

The volatilization daily peak from the urea $+0.15 \%$ $\mathrm{Cu}$ and $0.4 \% \mathrm{~B}$ occurred on the $7^{\text {th }}$ day $(8.1 \%)$ after the $3^{\text {rd }}$ application. This peak coincided with the one from the urea $+\mathrm{S}^{0}+$ polymers, though the ammonium daily loss in the preceding and following days reached high values, which contributed to a reduced volatilization compared with the regular urea. A similar situation was observed with the urea + polymers, which promoted an $\mathrm{N}-\mathrm{NH}_{3}$ loss of $9.6 \%$ on the $3^{\text {rd }}$ day after the $3^{\text {rd }} \mathrm{N}$ application. The urea + plastic resin had $3.8 \%$ volatilization 48 days after the $\mathrm{N}$ was applied and reached values near zero near the $66^{\text {th }}$ day from the application.

Therefore, in the $2^{\text {nd }}$ and $3^{\text {rd }} \mathrm{N}$ fertilizations of the coffee orchard, the ammonium nitrate did not contribute to the $\mathrm{N}^{-\mathrm{NH}_{3}}$ loss by volatilization, irrespective of the weather conditions.

Currently, there are few scientific databases (Fenilli, 2007) related to daily and accumulated loss of $\mathrm{N}^{-\mathrm{NH}_{3}}$ by volatilization from conventional (ammonium nitrate, urea and ammonium sulfate) and slow and controlled-release as well as stabilized fertilizers applied in Brazilian coffee orchards. On average, over the three $\mathrm{N}$ fertilizations, the urea $+0.15 \% \mathrm{Cu}+0.4 \% \mathrm{~B}$ and the plastic resin-coated urea reduced the losses of $\mathrm{N}_{-} \mathrm{NH}_{3}$ compared with the pure urea (Table 2).

The $\mathrm{N}$ loss associated with ammonium nitrate was only $1 \%$ of the total, as expected from similar studies on coffee orchards. From the total of $450 \mathrm{~kg} \mathrm{ha}^{-1}$ in three doses applied during 2013/2014, only $4.5 \mathrm{~kg} \mathrm{ha}^{-1}$ $\mathrm{N}-\mathrm{NH}_{3}$ was lost to the atmosphere as ammonia. The urea coated with polymers showed a loss of $35.8 \%$, which is higher than the loss observed for conventional urea $(31.2 \%)$.

The high loss of ammonia from anionic polymerscoated urea is due to the inefficacy of the additive formulation added to the urea that retains the ammonium in the negative charges of the polymer. This outcome reinforces the idea that coffee farmers should benefit from knowing the features of each technology and its efficiency before using it. 


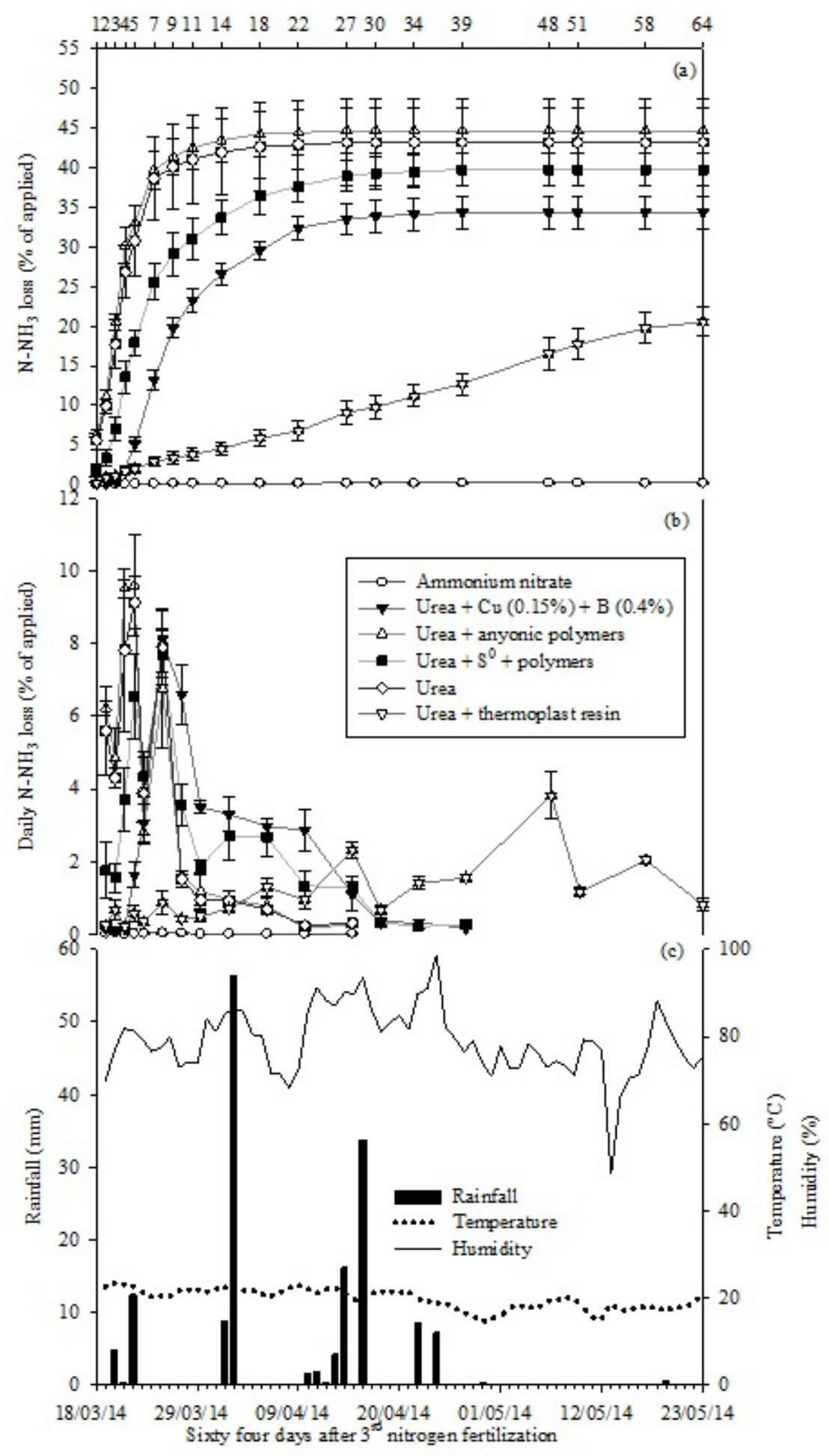

Figure 3: Accumulated (a) and daily (b) $\mathrm{N}-\mathrm{NH}_{3}$ loss, volatilized from fertilizers (conventional urea, ammonium nitrate, urea $+0.15 \% \mathrm{Cu}+0.4 \% \mathrm{~B}$, urea + anionic polymers, urea $+\mathrm{S}^{0}+$ polymers and urea + plastic resin), $3^{\text {rd }}$ application (150 kg ha-1) $\mathrm{N}$, in coffee orchard, relating to climate data (c). 
The $\mathrm{pH}$ in the soil surface layer $(0-5 \mathrm{~cm})$ is one of the chemical attributes that mostly affects the volatilization of ammonia to the atmosphere, and an increase in its value accelerates the loss (Watson et al., 2008; Menendez et al., 2009). In this study, the soil pH in the $0-5 \mathrm{~cm}$ layer was reduced from the $1^{\text {st }}$ to the $3^{\text {rd }} \mathrm{N}$ fertilization of coffee (Table 3 ). With the $\mathrm{N}$ application in the form of urea, the mean soil $\mathrm{pH}$ value after the $3^{\text {rd }}$ fertilization was 6.33 , and after the last fertilization, it decreased to 4.07; for the ammonium nitrate, the variations were 6.35 and 4.41 .

Several technologies used to enhance the efficiency of fertilizers were developed in the 1950s. However, fertilizers with an enhanced efficiency represent less than $1 \%$ of the total fertilizer used worldwide, though their prices have been decreasing.

The polymer-coated fertilizers (controlled release technology such as urea + resin) are eight to 12 times more expansive in terms of cost than the conventional fertilizers. Sulfur-coated urea is common in the Brazilian market and is the least expensive, though it is nearly twice as costly as regular urea. Moreover, sulfur-coated urea has been commercialized both alone and in the form of blends/mixtures. The urease inhibitors added to urea result in extra costs of approximately 15 - 30\% (Azeem, 2014; Timilsena et al., 2015).

Table 2: Accumulated N-NH3 loss from fertilizers (Conventional urea, ammonium nitrate, urea $+0.15 \% \mathrm{Cu}+$ $0.4 \% \mathrm{~B}$, urea + anionic polymers, urea $+\mathrm{S}^{0}+$ polymers and urea + plastic resin), in $1^{\text {st }}, 2^{\text {nd }}, 3^{\text {rd }}$ and total of three split nitrogen fertilization (450 $\left.\mathrm{kg} \mathrm{ha}^{-1}\right) \mathrm{N}$, in coffee orchard.

\begin{tabular}{ccccc}
\hline N-Fertilizer & $1^{\text {st }}$ fertilization & $2^{\text {nd }}$ fertilization & $3^{\text {rd }}$ fertilization & Mean \\
\hline & ----------------- \\
Urea + anionic polymers & $32.6 \mathrm{a}$ & $30.1 \mathrm{a}$ & $44.7 \mathrm{a}$ & $35.8 \mathrm{a}$ \\
Urea + 5 + polymer & $29.6 \mathrm{a}$ & $23.6 \mathrm{a}$ & $39.8 \mathrm{a}$ & $30.9 \mathrm{~b}$ \\
Urea & $28.3 \mathrm{a}$ & $22.1 \mathrm{a}$ & $43.2 \mathrm{a}$ & $31.2 \mathrm{~b}$ \\
Urea + 0.15\% Cu + 0.4\% B & $25.4 \mathrm{~b}$ & $17.1 \mathrm{~b}$ & $34.3 \mathrm{~b}$ & $25.6 \mathrm{c}$ \\
Urea + plastic resin & $1.4 \mathrm{c}$ & $3.7 \mathrm{c}$ & $20.5 \mathrm{c}$ & $8.6 \mathrm{~d}$ \\
Ammonium nitrate & $0.7 \mathrm{c}$ & $0.1 \mathrm{~d}$ & $0.2 \mathrm{~d}$ & $0.3 \mathrm{e}$ \\
\hline Mean & 11.2 & 8.1 & 19.0 & - \\
\hline Coefficient of variation (\%) & 17.1 & 11.8 & 16.9 & 11.3 \\
\hline
\end{tabular}

Means followed by the same lower case letter in the columns and upper case letter in lines do not differ from each other by the Skott-Knott test $(\mathrm{p} \leq 0.05)$.

Table 3: Values of $\mathrm{pH}$ in water at 0-5 cm soil layer and $\mathrm{N}-\mathrm{NH}_{3}$ loss (\%) from conventional urea, ammonium nitrate, urea $+0.15 \% \mathrm{Cu}+0.4 \% \mathrm{~B}$, urea + anionic polymers, urea $+\mathrm{S}^{0}+$ polymers and urea + plastic resin in the dose of $150 \mathrm{~kg} \mathrm{ha}^{-1}$ (Average of three fertilizations).

\begin{tabular}{cccccc}
\hline N-Fertilizer & $1^{\text {st (1) }}$ & Fertilization 2 ${ }^{\text {nd (2) }}$ & $3^{\text {rd (3) }}$ & After $^{\text {rd }}$ Fertilization & Volatilization $^{(4)}$ \\
\hline Urea & $6.33 \mathrm{bA}$ & $5.60 \mathrm{aB}$ & $4.70 \mathrm{bC}$ & $4.07 \mathrm{aC}$ & $31.2 \mathrm{D}$ \\
Ammonium nitrate & $6.35 \mathrm{bA}$ & $5.57 \mathrm{aB}$ & $4.63 \mathrm{bc}$ & $4.41 \mathrm{bB}$ & $1.0 \mathrm{~A}$ \\
Urea + 0.15\% Cu + 0.4\% B & $5.75 \mathrm{aA}$ & $5.73 \mathrm{aA}$ & $4.91 \mathrm{bB}$ & $4.91 \mathrm{bA}$ & $25.6 \mathrm{C}$ \\
Urea + polymers & $5.50 \mathrm{aA}$ & $5.37 \mathrm{aA}$ & $4.60 \mathrm{bB}$ & $4.06 \mathrm{aC}$ & $35.8 \mathrm{E}$ \\
Urea + So + polymers & $6.15 \mathrm{bA}$ & $5.4 \mathrm{aB}$ & $4.31 \mathrm{aC}$ & $3.82 \mathrm{aC}$ & $31.0 \mathrm{D}$ \\
Urea + plastic resin & $5.85 \mathrm{aA}$ & $5.77 \mathrm{aA}$ & $3.96 \mathrm{aB}$ & $4.07 \mathrm{aC}$ & $8.6 \mathrm{~B}$ \\
\hline Mean & 5.99 & 5.57 & 4.52 & 4.22 & 22.2 \\
\hline Coefficient of variation (\%) & 7.45 & 4.23 & 10.95 & 5.64 & 11.3
\end{tabular}

Means followed by the same lower case letter in the columns and upper case letter in lines do not differ from each other by the Skott-Knott test $(\mathrm{p} \leq 0.05) .{ }^{(1)} \mathrm{pH}$ in water at $0-5 \mathrm{~cm}$ depth before $1^{\text {st }}$ fertilization; ${ }^{(2)} 60$ days after $1^{\text {st }}$ fertilization; ${ }^{(3)} 60$ days after $2^{\text {nd }}$ fertilization. ${ }^{(4)}$ Mean over the three fertilizations. ${ }^{(5)}$ Mean of 60 days after fertilizer application. 
Currently, the cost of technologies in a decreasing order is controlled release $>$ slow release $>$ stabilized nitrogen fertilizers. To summarize, it is necessary to develop a new generation of cost-effective, slow, controlled-release and stabilized nitrogen fertilizers and to develop or improve the infrastructure of fertilizer plants in Brazil to reduce their cost. Advances in the nitrogen fertilizer technology could reduce the ammonia loss in coffee orchards. There are several fertilizers and technologies on the Brazilian market, such as those evaluated in this study.

\section{CONCLUSIONS}

In total of three nitrogen fertilization the accumulated nitrogen loss by volatilization from $\mathrm{N}$ fertilizers applied in coffee orchard was the following decrescent sequence: urea + polymers $(35.8 \%)>$ conventional urea $(31.2 \%)=$ urea $+7.9 \% \mathrm{~S}^{0}+$ polymers $(31.0 \%)>$ urea $+0.15 \% \mathrm{Cu}+$ $0.4 \% \mathrm{~B}(25.6 \%)>$ urea + plastic resin $(8.6 \%)>$ ammonium nitrate $(0.3 \%)$. Ammonium nitrate promotes the lowest loss by volatilization, irrespective of the climatic conditions after application. $\mathrm{N}$ fertilizers reduce soil $\mathrm{pH}$ after split $\mathrm{N}$ applications in coffee orchards.

\section{ACKNOWLEDGEMENTS}

The authors are thankfully acknowledge the financial support to the Minas Gerais Estate Research Foundation (FAPEMIG) and National Research and Development Council (CNPq) for the financial support to the research with conventional and innovative $\mathrm{N}$ fertilizer sources in tropical climate, Brazil and for the scholarships.

\section{REFERENCES}

AZEEM, B. et al. Review on materials \& methods to produce controlled release coated urea fertilizer. Journal of Controlled Release, 181:11-21, 2014.

BENINI, S. et al. Molecular details of urease inhibition by boric acid: Insights into the catalytic mechanism. Journal of the American Chemical Society, 126(12):3714-3715, 2004.

CANTARELLA, $H$. et al. Ammonia volatilization from urease inhibitor-treated urea applied to sugarcane trash blankets. Scientia Agricola, 65(4):397-401, 2008.

CHIEN, S. H.; PROCHNOW, L. I.; CANTARELLA, H. Recent developments of fertilizer production and use to increase nutrient efficiency and minimize environmental impacts. Advances in Agronomy, 102:261-316, 2009.
DU, C.; ZHOU, J.; SHAVIV, A. Release characteristics of nutrients from polymer-coated compound controlled release fertilizers. Journal of Polymers and Environment, 14(3): 223-230, 2006.

DU, C. et al. Prediction of nitrate release from polymercoated fertilizers using an artificial neural network model. Biosystems Engineering, 99(4):478-486, 2008.

FAN, X. H.; LI, Y. C. Nitrogen release from slow-release fertilizers as affect by soil type and temperature. Soil Science Society American Journal, 74(5):1635-1641, 2010.

FARIA, L. A. et al. Loss of from nitrogen fertilizers applied to maize and soybean straw. Revista Brasileira de Ciência do Solo, 37(4):969-975, 2013.

FENILLI, T. A. B. et al. Growth, development andfertilizer- ${ }^{15} \mathrm{~N}$ recovery by the coffee plant. Scientia Agricola, 64(5):541547, 2007.

FERREIRA, D. F. SISVAR: a computer statistical analysis system. Ciência e Agrotecnologia, 35(6):1039-1042, 2011.

GABROVSKA, K.; GODJEVARGOVA, T. Optimum immobilization of urease modified acrylonitrile copolymer membranes: Inactivation by heavy metals ions. Journal of Molecular Catalysis, 60(1-2):69-75, 2009.

HERINGER, D. D. Produto fertilizante a base de uréia e processo para fabricação do produto. PI 0700921-6 A. 10p, 2008.

KRAJEWSKA, B.; ZABORSKA, W.; CHUDY, M. Multi-step analysis of $\mathrm{Hg}^{2+}$ ion inhibition of jack bean urease. Journal of Inorganic Biochemistry, 98(6):1160-1168, 2004.

LARA-CABEZAS, W. A. R. et al. Calibration of a semi-open static collector for determination of ammonia volatilization from nitrogen fertilizers. Communications in Soil Science and Plant Analysis, 30(3-4):389-406, 1999.

LUPWAYI, N. Z. et al. Soil microbial community response to controlled-release urea fertilizer under zero tillage and conventional tillage. Applied Soil Ecolology, 45(3):254261, 2010.

MENENDEZ, S. et al. Effect of N-(n-butyl) thiophosphoric triamide and 3,4-Dimethylpyrazole phosphate on gaseous emissions from grasslands under different soil water contents. Journal of Environmental Quality, 38(1):2735, 2009.

NASCIMENTO, C. A. C. et al. Ammonia volatilization from coated urea forms. Revista Brasileira de Ciência do Solo, 37(4):1057-1063, 2013. 
OGLE, J. M.; SIMS, J. D. Controlled release fertilizer composition. US Pat. 20120240648, 2012.

PEREIRA, H. S. et al. Ammonia volatilization of urea in the outof-season corn. Revista Brasileira de Ciência do Solo, 33(6):1685-1694, 2009.

ROBERTS, J. R. Stabilized N-Alkyl thiphosphoric triamide solvent systems for use in nitrogen fertilizer. US Pat. 2014/0060132, 2014.

SANDERS, J. L.; MAZO, G.; MAZO, J. Anionic polymers composed of dicarboxylic acids and uses thereof. US Pat. 20080248954, 2008.

SANZ-COBENA, A. et al. Inhibitor of urease activity effectively reduces ammonia emissions from soil treated with urea under Mediterranean conditions. Agricultural, Ecosystems Environment, 126(3-4):243-249, 2008.

SHOJI, S. Innovative use of controlled availability fertilizers with high performance for intensive agriculture and environmental conservation. Science China Series, 48(2):912-920, 2005.

SILVA, D. R. G. et al. Productivity and efficiency of nitrogen fertilization in maize under different levels of urea and NBPT-treated urea. Ciência e Agrotecnologia, 35(3):516$523,2011$.

STAFANATO, J. B. et al. Volatilização de amônia oriunda de ureia pastilhada com micronutrientes em ambiente controlado. Revista Brasileira de Ciência do Solo, 37(3):726-732, 2013.

TIMILSENA, Y. P. et al. Enhanced efficiency fertilisers: a review of formulation and nutrient release patterns. Journal of the Science and Food Agriculture, 95(6):1131-1142, 2015.

TRENKEL, M. E. Slow and controlled-release and stabilized fertilizers: An option for enhancing nutrient use efficiency in agriculture. International Fertilizer Industry Association. Paris, 2010, 167p.

WANG, X.; CUI, J.; ZHOU, J. Ammonia volatilization of controlled-release urea enveloped with colophony from paddy field in typical red soil. Soils, 43(1):56-59, 2011.

WATSON, C. J. et al. Rate and mode of application of the urease inhibitor $\mathrm{N}$-(n-butyl) thiophosphoric triamide on ammonia volatilization from surface-applied urea. Soil Use Management, 24(3):246-253, 2008.

WILSON, M. L.; ROSEN, C. J.; MONCRIEF, J. F. Effects of polymercoated urea on nitrate leaching and nitrogen uptake by potato. Journal of Environmental Quality, 39(2):492499, 2010.

YANG, Y. Controlled release urea improved nitrogen use efficiency, activities of leaf enzymes, and rice yield. Soil Science Society American Journal, 76(6):2307-2317, 2012. 